\title{
What's Up with This Leadership Thing? Voices of African American Male College Undergraduates
}

\author{
Tammie Preston-Cunningham \\ Texas A\&M University \\ Barry L. Boyd \\ Associate Professor \\ Texas A\&M University \\ Chanda D. Elbert \\ Associate Professor \\ Texas A\&M University \\ Dr. Kim E. Dooley \\ Associate Dean, COALS \\ Texas A\&M University \\ Dr. Kelli Peck-Parrott \\ Clinical Professor \\ Director, SAAHE Program \\ Texas A\&M University
}

Assistant Director, Department of Student Activities

\begin{abstract}
This study investigates the perceptions of leadership of African American undergraduate males who attend a predominately-White institution in the Southwest after participation in a leadership development program. Research concerning African American undergraduate males in education has been from a deficit-orientated narrative and focused primarily on academic achievement or lack of involvement, with little attention paid to African American males performing leadership. As society continues to focus on graduation and college attendance by African American males, it is important to explore African American undergraduate male leadership as a viable method to engage and influence graduation and attendance. This study examines the way in which African American undergraduate males make meaning and define leadership. Results indicated that African American undergraduate males defined leadership as either leader behaviors or specific characteristics that leaders possess. The study indicates a need for leadership educators and student affairs professionals to develop and implement a common language concerning leadership with student leader
\end{abstract}




\section{INTRODUCTION}

The development of future leaders has been the original purpose and cornerstone of higher education since its inception (Dewey, 1916). According to Dewey, the role of educators is not to view education "as something, like filling a vessel with water, but rather [as] assisting a flower to grow in its own way" (Dewey, 1916, p. 38). The creation of an educated society has been promoted as the method to ensure that people prosper and evolve to their utmost potential (Sarason, 1971). As stated by Nohria and Khurana (2010), higher education is charged to develop the next generation of "leaders who possess the competency and character necessary to lead our modern society" (p. 3). Numerous studies have been published concerning the plight of African American males in the United States education system (Becker \& Becker, 2003; Bonner \& Bailey, 2006; Fashola, 2005; Fleming, 1984; Harper, 2003; Howard-Hamilton, 1997; Jackson \& Moore, 2006; Weatherspoon, 2005).

The need to explore plausible solutions due to the literature and how the media continued to depict African American males as unconcerned, unintelligent, and lacking the ability to lead or excel (Hooks, 2004; Majors \& Billson, 1992). Several studies informing the experiences of African American male college students have been conducted by (Harper, 2014; Bonner \& Bailey, 2006; Brown, 2006; Chavez, Guido-DiBrito \& Mallory, 2003). The most influential factor that informed the experiences of African American males was Black racial identity. While Byars-Winston (2010) identified being Black as central to identity for Blacks, DeCarlo (2005) argued that the impact of race was only recently "included and obliquely expounded upon in conceptual models of human development" (p. 36). Specifically for African American male college students, Allen (2000) and Gray (1995) noted continued low college matriculation and graduation rates of African American males as directly correlated to the decline of the African American family structure (Allen, 2000; Gray 1995). Several scholars have agreed that a relationship exists between environmental and cultural factors that influence human behavior, including academic performance and self-perception (Becker \& Becker, 2003; Brookover \& Erickson, 1969; Maxwell, 2004; Morrow \& Torres, 1995). The term and focus for this study is African American, which is consistent with the racial definition of the participants in the study.

According to Brown (2006), as some colleges and universities experience improvement in enrollment of African American males, the struggle to retain and graduate those students continues. Solórzano, Ceja, and Yosso (2010) contended that out-of-classroom experiences often play a significant role in African American male students' early departure from the university. The term microagressions was defined as subtle insults (verbal, nonverbal, and/or visual) directed toward people of color (Pierce, 1974). The microagressions ranged from behaviors such as peers not selecting them for study groups and organizations based on race to comments such as, "I don't want to work with you because you're Black." As noted by the researchers, the students stated that they felt hopeless, tired, discouraged, and prone to disengage from the university and that they performed poorly academically. Harper and Harris (2010) and Strayhorn and Terrell (2007) identified possible methods to address the needs of African American male college students that called for action by faculty and student affairs professionals. Due to the nature of student affairs professionals' roles as gatekeepers to student organizations, they have 
been thrust into the front lines in addressing the growing disparities between African American males and other males in higher education (Brown, 2006).

As student affairs professionals continue to grapple with engaging African American males, there must be intentionality in the design of campus opportunities to meet the needs of these students. This study sought to identify student involvement needs by assessing perceptions of leadership among African American male college students who participated in a gender-and race-specific college leadership development program. To examine and make meaning of African American male college students' perceptions of leadership, it was important to review relevant literature. In the following section, African American male identity, college student involvement for African American males, and leadership were reviewed to inform the study.

\section{African American Male Identity}

As a person discovers who they are and their personal role as defined by society the individual develops a sense of self (1968). The undergirding principle of a sense of self is that of the development of ego and identity which stems from social interaction. The study of identity development discusses the incorporated biological and racial perspectives and the influence on how individuals view themselves as compared to society. In an attempt to explain and understand African American male identity, the researcher reviewed literature relevant to African American racial identity, male gender identity, college male identity, and the intersection of each of these identities.

African American Racial Identity. Racial identity is "one of the most heavily researched areas that focuses on the psychological experiences of African Americans" (Sellers et al., 1998, p. 19) and includes attitudes and beliefs about being African American and part of the African American race (Decuir-Gunby, 2009). Cross and Fhagen-Smith (2001) and Sellers et al. (1998) are frequently cited in reviews of recent literature describing African American identity the use of both frameworks outline African American identity development to be socially constructed.

The Cross and Fhagen-Smith (2001) Lifespan model of Black Identity Development suggests cyclical stages over the course of the African American's life. African Americans with positive self-perceptions have a better understanding of being African American and actively engage with society as an African American. The multidimensional model of racial identity posed by Sellers et al. (1998) provides a theoretical framework for the significance that African Americans. The four dimensions of MMRI describe the significance and meaning of race in the self-concepts of African Americans: identity salience, centrality of identity, ideology associated with the identity, and regard in which the person holds African American people. Through testing this theory, a significant relationship between race and the self-identity of African Americans was identified (Sellers et al., 1997). Persons for whom race played a significant role in identity and who emphasized the uniqueness of being African American were more likely to participate in African American-centered activities and interact more with other African Americans (Sellers et al., 1997). 
The MMRI described salience as the belief in how much race plays a part in self-concept and is dependent on the context of the situation. The dimension of centrality is similar to salience in that it focuses on the individual's idea of the implication of race on self-concept; however, it is dependent on the individual's normal behavior versus situational behavior. The third dimension, ideology, was defined as how the individual feels that a member of the African American race should believe, behave, and offer opinions as related to interactions with other people in society. This dimension of ideology was described with four specific ideologies: (a) nationalist philosophy, focused on the importance and uniqueness of being of African descent; (b) oppressed minority ideology, highlighting the similarities between African Americans and other oppressed groups; (c) assimilationist philosophy, targeting the similarities between African Americans and the rest of American society; and (d) humanist philosophy, emphasizing the commonalities of all humans. These ideologies are manifested across four areas of functioning: politicaleconomic issues, cultural-social activities, intergroup relations, and interaction with the dominant group.

The final dimension, regard, may be defined as how a person feels about himself or herself. This dimension encompasses how a person positively feels toward other African Americans and being placed in that group. The public regard in this dimension consists of how the person believes others feel positively or negatively about African Americans, while the private regard relates to how the person feels, positively or negatively, about being placed in the African American group (Sellers et al., 1997).

Male Gender Identity. Kimmel (2010) suggested that males experience masculinity as a "homosocial enactment" whereby men "are under constant careful scrutiny of other men; "Other men watch us, rank us, grant our acceptance into the realm of manhood. Manhood is demonstrated for other men's approval" (p. 23). Majors and Billson (1992) also discussed masculinity as they introduced the concept of masculine attainment, a term that refers to the "persistent quest for gender identity" (p. 30). They contended that what constitutes a man is the ability to be responsible and provide for himself and his family. This challenge is heightened for Black males in America due to systemic racism. Systemic racism is defined as "Racialized exploitations and subordination of Americans of color by White Americans that encompasses the racial stereotyping, prejudices, and emotions of Whites, as well as the discriminatory practices and racialized institutions generated for the long term domination of African Americans and other people of color" (Feagin \& Barnett, 2005, p. 1100). The results of systemic racism of negative self-perception, overarching opinion that America is racist and a pessimistic outlook of the future negatively affect the African American college males' matriculate. African American males in college are less likely to hold the worldview that with hard-work you can be successful regardless of race and anyone may be successful (Levin, Federico, Sidanius, \& Rabinowitz, 2002).

College Male Gender Identity. Student affair professionals must refrain from developing students as compartmentalized entities due the multiple identities students possess which upon entering into college (Orbe, 2004). Chickering and Reisser (1993) and Harper and Harris (2010) informed this study concerning college male identity. 
Chickering and Reisser (1993) outlined concepts for college student development, including (a) developing competence, which is confidence in the ability to achieve a goal; (b) managing emotions, where students learn to identify and express emotions appropriately; (c) moving through autonomy toward interdependence, freeing students from needs for approval, as well as increasing decision-making abilities; (d) developing mature interpersonal relationships, where tolerance and appreciation of differences increase; (e) establishing identity as students begin to develop comfort with appearance and racial, gender, and sexual orientation, as well as a sense of self in social and cultural contexts; (f) developing purpose, as students develop the ability to establish commitments to personal interests, beliefs, and values; and ( $\mathrm{g}$ ) developing integrity, where abilities grow to balance self-interest with social responsibility. The stage of developing interpersonal relationships and establishing racial and gender identity directly influences this study. As African American college males are not only matriculating through college, but also experiencing these specific stages of the college study identity development there is direct impact on their matriculation. According to Harper and Harris (2010), "Understanding the development of college men requires examining their socially constructed experiences [because] masculinities have noticeable influences on the ways men experience college" (p. 18). The "noticeable influences" include how they develop friendships and where they allocate their out-of-class time, among other influences.

Intersection of Racial, Gender, and College Identity. The methodology of this study was informed by the multiple bodies of work concerning racial, gender, and college student identity. Sellers et al. (1998) noted the significance that African Americans assign to being African American as compared to their White counterparts. The layer of racial identity was often noted as more important than other aspects of their identity (Sellers, et al, 1998). Kimmel (2010) identified concepts of masculinity that are exercised as the need for approval by other men. Harper and Harris (2010) validated the need to capture socially constructed experiences to make sense of college male identity. Majors and Billson (1992) contributed the notion of male identity as a demonstration of personal responsibility and being a good provider. These scholars noted that this demonstration is not "straightforward achievement" for Black men:

Outlets for achieving masculine pride and identity, especially in political, economic, and educational systems, are more fully available to whites than to black males. This in turn restricts the Black man's ability to achieve in family systems, to take care of a wife and family, or to be a present and supportive father. (p. 31)

Chickering and Reisser's (1993) establishment of identity vector informed this study as African American males grow in their comfort levels with being African American, as well as male, on their college campuses.

\section{College Student Involvement for African American Males}

Astin (1996) suggested that student involvement is an important campus opportunity that correlates with student achievement and development. Tinto (1993) indicated that student organizations play an important role as agents of social integration for college students. Considering that social integration, specifically student involvement, has a direct impact on 
student retention and graduation, understanding the influence of student involvement on all students on college campuses should be a priority.

A study by Pascarella and Terenzini (1991) indicated that the higher frequency and quality of student involvement in out-of-class campus opportunities, the greater the students' educational aspirations, improved self-confidence, and increased interpersonal and leadership skills. Further, quality student involvement experiences have led to greater satisfaction with the university and decreased departures (Pascarella \& Terenzini, 1991; Tinto, 1993). Although student involvement has been recognized as beneficial, the task to ensure that these experiences are constructive and to integrate learning often rests on the shoulders of student affairs professionals (Strayhorn \& Terrell, 2007).

Involvement and engagement in out-of- class activities have positive effects on identity development for African American male college students (Cokley, 2001; Harper, 2006a, 2006b; Harper, Carini, Bridges, \& Hayek, 2004; Harper \& Quaye, 2009; Strayhorn, 2008). A study by Pascarella and Terenzini (1991) indicated that the higher frequency and quality of student involvement in out-of-class campus opportunities, the greater the students' educational aspirations, improved self-confidence, and increased interpersonal and leadership skills. Further, quality student involvement experiences have led to greater satisfaction with the university and decreased departures (Pascarella \& Terenzini, 1991; Tinto, 1993).Although research into the impact of leadership on African American male college students has increased, research concerning how African American college males frame or define leadership is minimal (Ospina \& Foldy, 2009). Research has explored experiences of African American male who assumed leadership roles in predominately White organizations and/or race-based organizations (Guiffrida, 2003; Kimbrough \& Harper, 2006; Sutton \& Terrell, 1997). There is minimal literature that discusses how African American males perceive leadership after assuming these positions (Harper, 2009). If student affairs professionals are to aid in creation of safe learning spaces in and out of the classroom for African American males, they must address the variables that may negatively influence student involvement experiences.

\section{Leadership Development}

There is increasing need by the world for workforce leaders equipped to work with a diverse workforce and higher education has been challenged with the task of developing these leaders. Leaders in society should be equipped to cultivate partnerships, address issues critically, and develop collaborations with local communities and key stakeholders (Ewing, Bruce, \& Ricketts, 2009). Higher education is tasked to produce not only technically competent leaders but also leaders who possess the ability to motivate and lead others different than themselves.

To meet this task, many colleges and universities have chosen to incorporate leadership development in their mission statements (Association of American Colleges and Universities, 2012; Astin \& Astin, 2000; Boatman, 1999; Guthrie, Jones, Osteen, \& Hu, 2013; Roberts, 2007) and have met this goal through encouragement of students to become involved in student organizations. The use of student organizations and leadership development has been well documented, as well as benefits of development of students as responsible citizens or leaders for 
the community and positive effects on social integration of students, regardless of race (Astin \& Astin, 2000; Harper \& Harris, 2010; Tinto, 1993).

Quality student involvement experiences, specifically taking on leadership roles in student organizations, require leadership skill development due to eventual transitions to leadership roles (Frazier, 2009). Leadership development concepts for college students, both in and out of the classroom, have been reflected in the literature for years (Keeling, 2004). In a study by Foreman and Retallick (2013), students who held a leadership position in a student organization scored significantly higher on the scales of consciousness of self, commitment, and individual values on the Socially Responsible Leadership Scale. Rubin, Bommer, and Baldwin (2002) reported that an extracurricular index score indicating the number of student organizations, leadership roles, and hours spent in those organizations significantly predicted development of skills such as communication, initiative, decision making, and teamwork. The concept of leadership has developed to be more relational, process oriented, service directed, and systems focused over the past 30 years.

As the concept of leadership has evolved, the face of higher education has also evolved. Universities and colleges have become more diverse and reflective of the changing demographics of the United States. It is expected that by 2042 the United States will become a minority majority country (U.S. Department of Commerce, Census Bureau, 2010); thus, the challenge to meet the initial charge of education-educating leaders for society-has become more daunting. Higher education has recognized the need to explore the intersection of leadership development and diversity (Guthrie et al., 2013). Student affairs professionals and leadership educators have a unique opportunity to address this challenge by developing opportunities to engage African American undergraduate males in student organizations and the activities of leadership.

Early attempts at development of leadership frameworks for African American college males were often generalized from studies that focused on students of colors in general (Ospina $\&$ Foldy, 2009). This practice did not account for the intersectionality of African American college males' multiple identities and removed the unique voice of this population (Guthrie et al., 2013). In order to develop leaders, student affairs practitioners and leadership educators must understand and legitimize the multiple identities of students (Chen \& Van Velsor, 1996).

As cited by Sutton and Terrell (1997), research was conducted concerning African American leadership in student organizations; however, very little research has focused specifically on African American males. Early research conducted on African American males often focused on barriers to involvement or experience after holding a leadership position; very few focused on the perceptions of leadership before assuming leadership roles or how African American college males framed their concepts of leadership (Frazier, 2009; Harper \& Quaye, 2009). The assumption by early researchers was that African American males did not assume leadership roles due to being unprepared, intimidated, or convinced that the leadership experience was irrelevant. The idea that African American males might construct their leadership framework differently from that of their White counterparts was not considered (Fleming, 1984; LaVant \& Terrell, 1994). 
A study by Sutton and Kimbrough (2001) indicated that African American undergraduate males did not view leadership as positional but instead as the role played in the organization. The term leader and the concept of leadership were associated with "acting White" or "trying to shine," both of which were viewed negatively (Arminio et al., 2000). In review of the limited literature concerning the voice of African American undergraduate males who participated in gender- and race-based college leadership development programs, I was led to explore this silenced population.

\section{Purpose of the Study}

The purpose of this qualitative study was to explore the perceptions and personal definitions of leadership held by African American male undergraduate participants in a raceand gender-based leadership development program at a predominately White institution (PWI) in the southwestern United States. The research questions used to frame the study were the following:

1) How do you define leadership?

2) What do you believe are key components of effective leadership?

\section{Methodology}

The two most common approaches to research are the quantitative and qualitative methods. The methods are dictated by different views of reality. The quantitative method relies on numerical values to express the data and is often used in large populations to construct generalities. A qualitative study is defined as an inquiry process of understanding a social or human problem, based on building a complex, holistic picture, formed with words, reporting detailed views of informants and conducted in a natural setting. The qualitative method is based on the assumption of multiple realities (Guba, 1990).

In this study, the qualitative method was used to offer a forum for participants' voices to be heard. The study employed the basic features of the phenomenological approach. According to Patton (1990), in phenomenological research there is a core to the meaning of common experience among participants. During the phenomenological research process, prior experiences and interest are shortly cast aside so as not to interfere with the research. This was important in the current study, which focused on second-semester freshmen African American males at a university in the south. The core framework of the research followed standards set forth by Moustakas (1994) that a phenomenological account should get inside the common experience of a group of people and describe the what, how, and meaning of that shared experience.

Based on past experience with the phenomena and willingness to participate, a purposive sample approach was used. Twelve participants were interviewed concerning their experiences with a college leadership program created for African American males at Big South University (BSU; a pseudonym) called Black Men Lead (BML; a pseudonym). The common phenomenon was the BML, an 8-week program for second-semester and sophomore African American males and was sponsored by the BSU National Pan-Hellenic Council (NPHC) fraternities, the governing council for historically African American fraternities and sororities. The BML 
program incorporated peer leaders, leadership skill training and leadership theory overview, life skills training, academic study groups, history of Blacks in the United States, Black identity development, small-group discussions, a leadership excursion, and a culmination project.

Setting and Context. I identified and invited study participants using a criterion and convenience sample (Appendix A). The study participants ranged in socioeconomic classification and academic major. All held a grade point average of 2.5 or higher and had participated in leadership positions in high school, had played a sport, or were members of a high school honor society. I collected data using 1-hour to 1.5-hour semi-structured interviews and transcribed and organized data into statements for data analysis. The statements were clustered into themes and evaluated across participant interviews for commonality and similarities.

Interviews. Each participant was informed of the purpose of the study and signed a consent form (Appendix B) prior to participation. The demographic data for each participant were collected prior to the study via the BML program application and interview. Participants were encouraged to use pseudonyms to ensure confidentiality and were offered opportunities to question the interviewer at the conclusion of the interview. The names of participants were withheld and distinguishable characteristics or comments were withheld from the final report. Each interviewee was assigned a numerical value to acknowledge identity.

The interviews were hosted on campus and lasted approximately an hour. Open-ended and guiding questions were generated based on the literature review. The interviews were transcribed by hand during the interview with no audio recording with each participant allowed to review my notes at conclusion of the interview. They varied in style, which allowed for free expression by the participant. I employed interview techniques such as paraphrasing, summarizing, and empathizing to develop rapport and insight into each student's experience. The questions focused on the BML experience, identity, perceptions, interactions with peers, and leadership. After coding the data from the first interview, each participant met with me in person or by telephone to discuss discrepancies between their statements and my interpretations.

Data Analysis. I analyzed the interview transcripts using the constant comparative method (Glaser \& Strauss, 1967). This method involved simultaneously performing a systematic coding and analysis of the data to generate research themes instead of beginning with a hypothesis in mind. The data were analyzed and assigned codes to categories that emerged from the data (Creswell, 1998; Lincoln \& Guba, 1985; Strauss \& Corbin, 1990). Techniques identified by Miles and Huberman (1994) and Moustakas (1994) were used to analyze data systematically. The analysis process began with a reading of the verbatim interview transcripts and was completed by a three-level coding method.

The first level of coding included "carefully examining the data and selecting phrases, words, and stories when observed individually contains a single unit of meaning" (Schreiber \& Stern, 2001, p. 69). The first-level coding included a review of the interview transcript and making notations on the notecard to identify key words or phrases. The second level of coding was "examining and collapsing codes into categories or higher-level concepts" (Schreiber \& Stern, 2001, p. 70). As the data were reviewed and analysis continued, it was important to note 
convergences and divergences among categories. In the third level of coding, relationships among categories were observed and final themes emerged (Schreiber \& Stern, 2001).

During the qualitative research process, it was important to address four areas suggested by Lincoln and Guba (1985) to ensure trustworthiness were: truth value, applicability, consistency, and neutrality. My experience in student affairs (more than 10 years), as well as my role as designer of the BML program, added to confidence and truth value in the interpretation of the data. Member checks were achieved (a) by sending the overarching themes to the participants with requests to add or delete any comments, and (b) by debriefing in conference with colleagues in the student affairs area who work exclusively with the study population to address consistency and neutrality.

To analyze the data, a master list of categories and themes was developed and compared to current conceptual and theoretical frameworks. Peer debriefing was conducted with members of the dissertation committee and fellow student development professionals to ensure neutrality. The issue of applicability could not be addressed because the BML experience is a unique phenomenon; however, transferability may be inferred. The context of applicability relies on the perspective of the reader; however, the reader is urged not to generalize across racial identities or university settings. Phenomenological studies are designed to gain insight into the world of the participant who experience a particular phenomenon.

\section{Results}

The experiences of the 12 participants were examined and four broad themes emerged during analysis. The themes were divided into two categories: (a) perceived behaviors of leaders/participants, and (b) traits that leaders/participants possessed. The themes were (a) influence and motivation, (b) selflessness/responsibility, (c) awareness, and (d) performance of specific behaviors (integrity, honesty, initiative, and good communication). The presentation of results uses pseudonyms and participant direct quotes, with the cited participant identified by a code number.

Influence and Motivation. Participants strongly agreed that leaders should be able to influence and motivate others, especially other African American undergraduate males. They agreed that being a role model was intertwined with influence and motivation. Specifically, they stated that it was important to be a role model to other African American males on campus and at home $(1,2,3,4,6,7,8,9,10)$.

I heard a saying once that said you can lead a horse to water but if you cannot make them drink, then you are really not a leader. A leader is going to make sure the horse drinks the water because of their ability to influence. (2)

I look to a leader as someone I can look up to. You cannot choose your manager but you can choose your leader. (4)

Leadership is a person or group of people that inspires people to do something that they wouldn't normally do. Leadership impacts others' lives in a positive way. (8) 
Selflessness/Responsibility. Participants stated that they expected the leader to be selfless and engage followers in decision making. They said that the leader should be committed and feel a responsibility to followers. They identified the need to be the best and to take one for the team, noting that they had to represent all African American men to their White counterparts in and out of the classroom. It was even more important to serve the organization well to ensure that it would be easier for future members of the [Black] organization $(1,2,3,4,6,7,8,10)$.

I am not selfish but selfless. I'm going to get people engaged in decision making. (4) You have to be able to take on all the pressures and challenges [of the organization] and not complain. (7)

A leader will want to do it for the good of the cause and not for fame. I am more of a servant leader. (9)

You have a commitment to make sure the organization is successful and there is no benefit to you other than the good of what you are working for.(10)

Awareness. Study participants identified the need for leaders to be aware of themselves and their followers in order to be effective and lead. The leader should be selected by members and not self-appointed, to ensure that the leader is not doing it for the wrong reason, or in order to be seen. One participant discussed at length the importance of leaders possessing emotional intelligence and making positive impacts on followers $(1,2,3,7,9,10,12)$.

Got to know who you are. If you got to tell me who you are, that's not who you are, that's just somebody you want to be. (1)

Have to be understanding of your followers and know where they are coming from and their challenges. You need to understand who you are leading. You have to be a spokesperson and so you have to understand and know your people. (7)

You have to be aware of what is going around you, making sure you know what is going on in your culture. (10)

I believe emotional intelligence is important, because it helps knowing your people and their strengths and weaknesses. Because if you put them in a position where you know they are going to fail, they will fail. (12)

Leadership Behaviors. Participants identified specific desirable leadership behaviors that a leader should perform or that they viewed themselves performing, such as communicating effectively, being an active listener, and being open-minded, decisive, a self-starter, and knowledgeable. Several participants stated that it was important to be unique in order to stand out and lead extraordinary people $(1,2,4,5,8,10,11)$.

Not judging everybody because people come from a different lenses and cultural barrier. Not trying to put your own experiences onto everybody. (1) A leader should be able to make changes quickly and be knowledgeable. For example, you don't want to ask a teacher a question and they don't have an answer. They should be knowledgeable in what they are doing. (4) Communication is key; you have to communicate effectively if you want to be efficient as an organization. You have to have the ability to trickle down information. (5) 
Effective leadership requires willingness to listen to the opinions and thoughts of others and actually consider them. (11)

\section{Discussion}

As stated by Astin and Astin (2000), student organizations play an important role in social integration for college students and are invaluable in offering opportunities for leadership development. Four major themes emerged from the study: leaders influence and motivate followers, leaders are aware of self and others, leaders exhibit selflessness and responsibility, and leaders perform specific leadership behaviors. Dimensions of leadership that emerged from the data included leader traits, leader behaviors, and the concept of servant leadership.

Leader Traits. Northouse (2013) identified a set of leadership traits based on a retrospective examination of research (Kirkpatrick \& Locke, 1991; Lord, DeVader, \& Alliger, 1986; Stogdill, 1948, 1974; Zaccaro, Kemp, \& Bader, 2004). The major leadership traits that were identified were intelligence, self-confidence, determination, integrity, and sociability. The participants in the current study frequently described themselves and leader desirable traits to be honest, effective communicator, confident, knowledgeable, relatable, possessing integrity, applying ethics in decision making, self-starters, determined, and trustworthy. The traits identified by the participants were more aligned with the earlier traits noted by Stogdill (1974) in research in which African American males were not the focus population. Stogdill's research identified the leadership traits of self-confidence, drive for responsibility, vigor and persistence, initiative, self-confidence and personal identity, influence others behavior, and design social interaction with purpose, which aligned with the results also found in this study.

Leader Behaviors. As described by Fairholm (2002), leadership is not merely mechanics, styles, behaviors, or characteristics of leaders; instead, leadership is a holistically and philosophical enactment that entails values, motives, power, and the aspirations and needs of both follower and leader. In this regard, Lussier and Achua (2007) identified nine behaviors of effective leaders: (a) dominance, (b) high energy, (c) self-confidence, (d) locus of control, (e) stability, (f) integrity, (g) intelligence, (h) emotional intelligence, and (i) flexibility and sensitivity to others.

The themes that emerged in this study aligned with the behaviorist concept of leadership. Participants stated that influencing and motivating others was significant for their community (African American males) due to the low level of African American male student organization involvement on campus. They indicated that, in order to be a role model and encourage other African American males to become involved, the leader must be able to influence and motivate hesitant peers.

As noted in studies completed by Kimbrough and Harper (2006) and Strayhorn (2008), African American undergraduate males often assumed responsibility to portray the entire race in interactions with other races. Participants in the current study stressed the importance of role modeling for other African American males on campus to dispel African American male negative behavior stereotypes. They also recognized that being able to influence others was not 
always connected to holding a formal leadership position in a student organization. One student discussed at length his experience with a specific student organization and their election of a less influential and competent president due to the climate and politics of the organization.

The participants reflected that it was important that leaders understand and be aware of followers' and their own personal strengths and weakness in order to advance and serve the organization, which position aligns with the ideology of collectivism. The foundation of collectivism was the premise that leadership is a collective endeavor (Guthrie et al., 2013). The ideology of collectivism emerged as a method to develop diverse students' leader identity (Bordas, 2007). According to Bordas (2007), diverse college students reported that uplift of the community relied on empowerment of the individual. As the leader develops and empowers the follower, the community is advanced and improved. This viewpoint aligns with the servant leadership style approach.

Servant Leadership. Researchers have debated the servant leadership approach as both trait and behavior based (Laub, 2003). Laub reported that servant leadership was viewed as a behavior process and that students focused on the behaviors that encapsulate servanthood. The study indicated that African American males' definition of leadership aligned with many of the tenets of servant leadership. The foundation of servant leadership is the idea of a leader being a servant to the people being led (Spears, 1998). The highest duty of a leader is to address the highest-priority needs of others (Greenleaf, 2002).

According to Russell (2001) and Russell and Stone (2002), an essential component of servant leadership is the value of integrity and competence to establish interpersonal trust with followers. Rost (1993) indicated that anyone in the hierarchical setting can be identified as a leader and anyone can be a follower (Rost, 1993). The use of the servant leadership style when working with college-age African American men allows for incorporation of multiple layers of identity due to incorporation of self-awareness and support by followers who are growing not only as members of the organization but also as individuals (Riverstone, 2004).

The servant leadership style may provide African American men the voice to encourage their followers but still exude self-confidence. The leadership style of African American men to show strength but remain nurturing is encouraged in the servant leadership model due to its focus on making followers better than they were before. One of the key components of servant leadership is the leader offering followers opportunities to be successful and provide ideas to the organization; this component is in alignment with the consideration characteristics that are a mark of the African American leadership style. Self-awareness and a servant mindset may assist African American men as they navigate their student organization's complexities.

\section{Implications}

This study reflects specifically on the role that student affairs practitioners and leadership educators may play on university campuses. This study concluded that African American undergraduate males defined and perceived leadership in ways similar to those reported in previous research; however, there remains confusion regarding the terms leader and leadership. 
Participants used descriptors to define leader and leadership, even after participating in a leadership development program. The interchangeable use of the terms leader and leadership for college students is a conundrum. Student affairs professionals and leadership educators must embrace and share with student leaders a common language pertaining to the terms leadership and leader.

As Arminio and colleagues (2000) found, students of color did not value the label of leader in the same way as their White counterparts. As indicated in this study, African American males were unconcerned with the formal title of leader but thought it more important to perform the behavior of a leader and be identified by peers as a leader rather than hold a formal position. Past studies have focused exclusively on students who held formal positions, which does not account for African American males who were perceived by peers and who perceived themselves to be leaders and engaged in leadership. To give a truthful and robust voice to this population, future researchers must consider this paradigm when designing studies.

Student affairs administrators must be cognizant of the convergence of multiple identities that African American undergraduate males encounter on college campuses, coupled with the servant leadership approach. The servant leadership approach may be overplayed to ensure follower and organization success. As cautioned by Block (1993) concerning students and servant leadership, student leaders may be tempted to assume too much responsibility, to their personal detriment. Student affairs professionals and leadership educators must take this into consideration when engaging these students and be intentional in conversations concerning life balance and obligations.

\section{Recommendations}

As student affairs pro-African American college male's increased satisfaction with the university and leadership paradigms cannot be attributed solely to campus-wide involvement, but African American males appreciate and seek these opportunities. African American men have different experiences and conceptual ideas of leadership, leading to the need for dynamic and distinct leadership opportunities. Participation in campus-wide organizations provides students with leadership skills, but many students require safe spaces to enhance and develop personal leadership skills.

Defining the problem in education with regard to African American college male students as solely an outcome of society does not recognize the roles that faculty and student affairs professionals play (Walker, 2009). Faculty and student affairs professionals are charged with creating safe spaces for learning and development on campus for all students; however, the creation of learning and developing spaces often relies on external factors such as other students and the surrounding community. Students often experience the most learning and developing in student organizations. Safe spaces for students of color rely not only on physical locations but also on emotionally and intellectually safe spaces. Students must have a sense of safe space to express not only their emotions but also their intellectual capacity. As one interviewee stated, it was important to be able to express his emotions with other men without fear of ridicule or reprisal. The beliefs of many African American undergraduate males that there exists no place in 
the classroom or in the extracurricular realm to express emotions or intelligence freely is detrimental to their development as students and as men. Student affairs practitioners should create and offer safe places to train and educate African American undergraduate males. The leadership development program should ensure that multiple identities are addressed.

Attention must be paid to inextricably intertwine technical, cultural, and political components to create not only well-intentioned but also well-planned and well-implemented programs. Research strongly implies that social integration plays a vital role in African American males' student success in college. African American male students should be encouraged to become involved in campus-sponsored activities during their first year. Freshmen orientation programs that exemplify a friendly and inclusive community should be implemented. Student organizations should be instructed on successful recruitment plans to encourage African American male student participation.

\section{References}

Allen, X. M. (2000). Family functioning and the academic self-efficacy and academic achievement of African American male freshmen and sophomore college students (Unpublished doctoral dissertation). The University of North Carolina, Greensboro, NC.

Arminio, J. L., Carter, S., Jones, S. E., Kruger, K., Lucas, N., Washington, J., Scott, A. (2000). Leadership experiences of students of color. NASPA Journal, 37, 496-510.

Association of American Colleges and Universities. (2012). A crucible moment: College learning and democracy's future. Washington, DC: Author.

Astin, A. W. (1996). Involvement in learning revisited: Lessons we have learned. Journal of College Student Development, 37(2), 123-134.

Astin, A. W., \& Astin, H. S. (Eds.). (2000). Leadership reconsidered: Engaging higher education in social change. Battle Creek, MI: W. K. Kellogg Foundation.

Becker, G. S., \& Becker, G. S. (2003). How to level the playing field for young Black men. Business Week, 3844, 24.

Block, P. (1993). Stewardship: Choosing service over self-interest. San Francisco, CA: BerrettKoehler.

Boatman, S. A. (1999). The leadership audit: A process to enhance the development of student leadership. NASPA Journal, 37, 325-336.

Bonner, F. A., II, \& Bailey, K. W. (2006). Enhancing the academic climate for African American college men. In M. J. Cuyjet (Ed.), African American men in college (pp. 24-46). San Francisco, CA: Jossey-Bass.

Bordas, J. (2007). Salsa, soul, and spirit: Leadership for a multicultural age. San Francisco, CA: Berrett-Koehler. 
Brookover, W., \& Erickson, E. (1969). Society, schools, and learning. East Lansing, MI: Michigan State University Press.

Brown, C. (2006). The impact of campus activities on African American college men. In M. J. Cuyjet (Ed.), African American men in college (pp. 47-94). San Francisco, CA: JosseyBass.

Byars-Winston, A. (2010). The vocational significance of Black identity: Cultural formulation approach to career assessment and career counseling. Journal of Career Development, 37, 441-464.

Chavez, A. F., Guido-DiBrito, F., \& Mallory, S. L. (2003). Learning to value the other: A framework of individual diversity development. Journal of College Student Development, 44, 453-469.

Chen, C. C., \& Van Velsor, E. (1996). New directions for research and practice in diversity leadership. Leadership Quarterly, 7, 285-302.

Chickering, A. W., \& Reisser, L. (1993). Education and identity (2nd ed.). San Francisco, CA: Jossey-Bass.

Cokley, K. (2001). Gender differences among African American students in the impact of racial identity on academic psychosocial development. Journal of College Student Development, 42, 480-487.

Creswell, J. W. (1998). Qualitative inquiry and research design: Choosing among five traditions. Thousand Oaks, CA: Sage.

Cross, W. E., \& Fhagen-Smith, P. E. (2001). Patterns of African American identity development: A life span perspective. In C. L. Wijeyesinghe \& B. W. I. Jackson (Eds.), New perspectives on racial identity development: A theoretical and practical anthology (pp. 243-270). New York, NY: New York University.

DeCarlo, A. (2005). Identity matters: A new intervention threshold for work practitioners working with African American adolescents. Child and Adolescent Social Work Journal, 22(1), 35-55.

Decuir-Gunby, J. T. (2009). A review of the racial identity development of African American adolescents: The role of education. Review of Educational Research, 79(1), 103-124.

DeSousa, D. J.,\& King, P. M. (1992). Are White students really more involved in collegiate experiences than Black students? Journal of College Student Development, 33, 363-369.

Dewey, J. (1916). Democracy and education. New York, NY: Macmillan.

Erickson, E. (1968). Identity, youth, and crisis. New York, NY: Norton.

Ewing, J. C., Bruce, J. A., \& Ricketts, K. G. (2009). Effective leadership development for undergraduates: How important is active participation in collegiate organizations? Journal of Leadership Education, 7(3), 118-131. 
Fairholm, M. R. (2002). Leading from the middle: The power and influence of middle leaders. Public Manager, 30(4), 17-22.

Fashola, O. (2005). Educating African American males. Thousand Oaks, CA: Corwin.

Feagin, J. R., \& Barnett, B. M. (2005). Success and failure: How systemic racism trumped the Brown v. Board of Education decision. University of Illinois Law Review, 2004(5).

Fleming, J. (1984). Blacks in college. San Francisco, CA: Jossey-Bass.

Foreman, E. A., \& Retallick, M. S. (2013). Using involvement theory to examine the relationship between undergraduate participation in extracurricular activities and leadership development. Journal of Leadership Education, 12(2), 56-73.

Frazier, T. L. (2009). African American college men holding leadership roles in majority white student groups (Unpublished dissertation). Iowa State University, Ames, IA.

Glaser, B. G., \& Strauss, A. L. (1967). The discovery of grounded theory: Strategies for qualitative research. New York, NY: Aldine De Gruyter.

Gray, H. (1995). Watching race: Television and the struggle for blackness. Minneapolis, MN: University of Minnesota Press.

Greenleaf, R. (2002). The servant as leader. Mahwah, NJ: Paulist Press.

Guba, E. (1990). The paradigm dialog. Beverley Hills, CA: Sage.

Guiffrida, D. (2003). African American student organizations as agents of social integration. Journal of College Student Development, 44, 304-319. doi:10.1353/csd.2003.0024

Guthrie, K. L., Jones, T. B., Osteen, L., \& Hu, S. (2013). Cultivating leader identity and capacity in students from diverse backgrounds (ASHE Higher Education Report AEHE 39:4). New York, NY: Wiley.

Harper, S. R. (2003). Most likely to succeed: The self-perceived impact of involvement on the experiences of high-achieving African American undergraduate men at predominantly White universities (Unpublished doctoral dissertation). Indiana University, Bloomington, IN.

Harper, S. R. (2006a). Enhancing African American male student outcomes through leadership and active involvement. In M. J. Cuyjet (Ed.), African American men in college (pp. 6894). San Francisco, CA: Jossey-Bass.

Harper, S. R. (2006b). Peer support for African American male college achievement: Beyond internalized racism and the burden of "acting White." Journal of Men's Studies, 14, 337358. 
Harper, S. R. (2009). Institutional seriousness concerning Black male student engagement: Necessary conditions and collaborative partnerships. In S. R. Harper \& S. J. Quaye (Eds.), Student engagement in higher education: Theoretical perspectives and practical approaches for diverse populations (pp. 137-156). New York, NY: Routledge.

Harper, S. R. (2014). (Re) setting the agenda for college men of color. In R. A. Williams (Ed.), Men of color in higher education: New foundations for developing models for success (pp. 116-143). Sterling, VA: Stylus.

Harper, S. R., Carini, R. M., Bridges, B. K., \& Hayek, J. C. (2004). Gender differences in student engagement among African American undergraduates at historically Black colleges and universities. Journal of College Student Development, 45, 271-284.

Harper, S. R., \& Harris, F., III. (2010). College men and masculinities: Theory, research, and implications for practice. San Francisco, CA: Jossey-Bass,

Harper, S. R., \& Quaye, S. J. (2009). Student engagement in higher education. New York, NY: Routledge.

Hooks, B. (2004). We real cool: Black men and masculinity. New York, NY: Routledge.

Howard-Hamilton, M. F. (1997). Theory to practice: Applying developmental theories relevant to African American men. New Directions for Student Services, 80, 17-30.

Jackson, J., \& Moore, J. (2006). African American males in education: Endangered or ignored? Teachers College Record, 108, 201-205.

Keeling, R. P., (2004). Learning reconsidered: A campus-wide focus on the student experience. Washington, DC: National Association of Personnel Administrators and the American College Personnel Association.

Kimbrough, W. M., \& Harper, S. R. (2006). African American men at historically Black colleges and universities: Different environments, similar challenges. In M. J. Cuyjet (Ed.), African American men in college (pp. 189-209). San Francisco, CA: Jossey-Bass.

Kimmel, M. (2010) Misframing men: Essays on the politics of contemporary masculinities. New Brunswick, NJ: Rutgers University Press.

Kirkpatrick, S. A., \& Locke, E. A. (1991). Leadership: Do traits matter? Academy of Management Executives, 5(2), 47-60.

Laub, J. (2003). From paternalism to servant: Organizational Leader Ship Assessment (OLA) model. International Journal of Servant Leadership, 1(1), 155-186.

LaVant, B. D., \& Terrell, M. C. (1994). Assessing ethnic minority student leadership and involvement in student governance. In M. C. Terrell \& M. J. Cuyjet (Eds.), Developing student government leadership (pp. 59-71). San Francisco, CA: Jossey-Bass.

Levin, S., Federico, C., Sidanius, J., \& Rabinowitz, J. (2002). Social dominance orientation and intergroup bias: The legitimation of favoritism for high-status groups. Personality and Social Psychology Bulletin, 28, 144-157. 
Lincoln, Y. S., \& Guba, E. G. (1985). Naturalistic inquiry. Beverly Hills, CA: Sage.

Lord, R. G., DeVader, C. L., \& Alliger, G. M. (1986). A meta-analysis of the relation between personality traits and leadership perceptions: An application of validity generalization procedures. Journal of Applied Psychology, 71, 402-410.

Lussier, R., \& Achua, C. (2007). Leadership: Theory, application, and skill development (3rd ed.). Mason, $\mathrm{OH}$ : Thomson.

Majors, R., \& Billson, J. M. (1992). Cool pose: The dilemmas of Black manhood in America. New York, NY: Simon \& Schuster.

Maxwell, B. (2004). On campus: Grim statistics for African American men. Retrieved from http://www.sptimes.com/2004/01/04/Columns/ On_campus grim_stati.shtml

Miles, M. B., \& Huberman, A. M. (1994). Qualitative data analysis: An expanded sourcebook (2nd ed.). Thousand Oaks, CA: Sage.

Morrow, R., \& Torres, C. (1995). Social theory and education. Albany, NY: SUNY Press.

Moustakas, C. (1994). Phenomenological research methods. Thousand Oaks, CA: Sage.

Nahavandi, A. (2006). The art and science of leadership (4th ed.). Upper Saddle River, NJ: Pearson Prentice-Hall.

Nohria, N., \& Khurana, R. (2010). Advancing leadership theory and practice. In N. Nohria \& R. Khurana (Eds.), Handbook of leadership theory and practice (pp. 3-26). Boston, MA: Harvard Business School Press.

Northhouse, P. G. (2013). Leadership: Theory and practice (6th ed.). Thousand Oaks, CA: Sage.

Orbe, M. (2004). Negotiating multiple identities within multiple frames: An analysis of firstgeneration coflege stadents. Communication Education, 53(2), 131-149. doi:10.1080/03634520410001682401

Ospina, S., \& Foldy, E. (2009). A critical review of race and ethnicity in the leadership literature: Surfacing, context, power, and the collective dimensions of leadership. Leadership Quarterly, 20, 876-896.

Pascarella, E. T., \& Terenzini, P. T. (1991). How college affects students: Findings andinsights from twenty years of research. San Francisco, CA: Jossey-Bass.

Patton, M. Q. (1990). Qualitative evaluation and research methods (2nd ed.). Newbury Park, CA: Sage.

Pierce, C. (1974). Offensive mechanisms. In F. Barbour (Ed.), The Black seventies (pp. 265282). Boston, MA: Porter Sargent.

Polkinghorne, D. E. (1989). Phenomenological research methods. In R. S. Valle \& S. Halling (Eds.), Existential phenomenological perspectives in psychology (pp. 41-60). New York, NY: Plenum. 
Riverstone, L. (2004). Servant leadership: A manifestation of postmaterialism? Global Virtue Ethics Review, 5(3), 95-119.

Roberts, D. C. (2007). Deeper learning in leadership: Helping college students find the potential within. San Francisco, CA: Jossey-Bass.

Rost, J. (1993). Leadership for the twenty-first century. New York, NY: Praeger.

Rubin, R. S., Bommer, W. H., \& Baldwin, T. T. (2002). Using extracurricular activity as an indicator of interpersonal skill: Prudent evaluation or recruiting malpractice? Human Resource Management, 41, 441-454.

Russell, R. F. (2001). The role of values in servant leadership. Leadership and Organization Development Journal, 22(2), 76-85. doi:10.1108/01437730110382631

Russell, R. F., \& Stone, A. G. (2002). A review of servant leadership: developing a practical model. Leadership and Organization Development Journal, 23(3), 145-157. doi:10.1108/01437730210424

Sarason, S. B. (1971). The culture of the school and the problem of change. Boston, MA: Allyn \& Bacon.

Schreiber, R. S., \& Stern, P. N. (Eds.). (2001). Using grounded theory in nursing. New York, NY: Springer.

Sellers, R., Smith, M., Shelton, J., Rowley, S., \& Chavous, T. M. (1998). Multidimensional model of racial identity: A reconceptualization of African American racial identity. Personality and Social Psychology Review, 2(1), 18-39. doi:10.1207/s15327957pspr0201_2

Solórzano, D. G., Ceja, M., \& Yosso, T. J. (2010). Critical race theory, racial micro-aggressions, and campus racial climate: The experiences of African American college students. Journal of Negro Education, 69(1/2), 60-73.

Spears, L. (1998). Insights on leadership: Service, stewardship, spirit, and servant leadership. New York, NY: Wiley.

Stogdill, R. M. (1948). Personal factors associated with leadership: A survey of the literature. Journal of Psychology, 25, 35-71.

Stogdill, R. M. (1974). Handbook of leadership: A survey of theory and research. New York, NY: Free Press

Strauss, A., \& Corbin, J. (1990). Basics of qualitative research: Grounded theory procedures and techniques. London, UK: Sage.

Strayhorn, T. L. (2008). The role of supportive relationship in facilitating African American males' success in college. NASPA Journal, 45(1), 26-48.

Strayhorn, T. L., \& Terrell, M. C. (2007). Mentoring and satisfaction with college for Black students. Negro Educational Review, 58(1-2), 69-83. 
Sutton, E. M., \& Kimbrough, W. M. (2001). Trends in Black students involvement. NASPA Journal, 39(1), 30-40.

Sutton, E. M., \& Terrell, M. C. (1997). Identifying and developing leadership opportunities for African American men. New Directions for Student Services, 80, 55-64.

Tinto, V. (1993). Leaving college: Rethinking the causes and cures of student attrition. Chicago, IL: University of Chicago Press.

U.S. Department of Commerce, Census Bureau. (2010). It's in our hands. Retrieved from http://www.census.gov/

Weatherspoon, F. (2005). The status of African American males in higher education and employment. Athens, GA: Georgia State University, African American Male Initiative.

Zaccaro, S. J., Kemp, C., \& Bader, P. (2004). Leader traits and attributes. In J. Antonakis, A. T. Cianciolo, \& R. J. Sternberg (Eds.), The nature of leadership (pp. 101-124). Thousand Oaks, CA: Sage. 


\section{Author Biographies}

Dr. Preston-Cunningham currently serves as the Assistant Director in Department of Student Activities at Texas A\&M University and has worked in higher education for 23 years. Dr. Preston-Cunningham earned her doctorate at Texas A\&M University in Agriculture Leadership Education and Communication with an emphasis on student development.

Dr. Barry L. Boyd is an Associate Professor in the Department of Agricultural Leadership, Education, \& Communications at Texas A\&M University. He teaches courses in personal leadership development, and applied ethics. Dr. Boyd's research focuses on teaching effectiveness, assessment of student learning, and teaching for critical thinking in the classroom.

Dr. Chanda D. Elbert is an Associate Professor in the Department of Agricultural Leadership, Education and Communications at Texas A\&M University. Her teaching and research interest areas include leadership, diversity and program evaluation.

Dr. Kim E. Dooley is the Associate Dean for Academic Operations for the College of Agriculture and Life Science and Professor in the Department of Agricultural Leadership, Education and Communications. She has worked at Texas A\&M University for 25 years.

Dr. Kelli Peck Parrott is the Director for the Student Affairs Administration in Higher Education Program and a Clinical Professor at Texas A\&M University. She earned her Ph.D. in Educational Administration from Bowling Green State University. She has held positions in the Office of the Provost, Dean of Students, Student Activities, Residence Life, Student Conduct, and Student Disability Services. 